\begin{tabular}{lll}
\hline Jurnal Pendidikan Dasar Perkhasa & \\
& & P-ISSN 2461-078X \\
E-ISSN 2654-783X
\end{tabular}

\title{
PENINGKATAN AKTIVITAS DAN HASIL BELAJAR IPS KELAS IV MELALUI PENERAPAN MODEL PEMBELAJARAN KOOPERATIF TIPE ROLE PLAYING BERBANTUAN BONEKA WAYANG
}

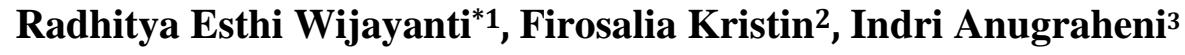 \\ 1,2,3Program Studi PGSD, Universitas Kristen Satya Wacana \\ Diterima: 21 Maret 2019. Dipublikasi: 5 April 2019.
}

\begin{abstract}
The purpose of this study is to improve the activities and learning outcomes of students in social studies subjects using a learning model. This type of research is classroom action research that has been carried out in two cycles. In each cycle through 4 stages, namely planning, action, observation and reflection. This research was carried out in SD Negeri Patemon 01 with research subjects in fourth grade students of SD Negeri Patemon 01 with a total of 26 students. Data collection tools using are interviews, observations, and tests. The results showed that by applying the cooperative learning model of the Role Playing type assisted by puppet puppet media, it could improve the activities and learning outcomes of social studies on thematic learning in fourth grade SD Negeri Patemon 01 students. Pre-cycle action activities with an average of 44.46 have sufficient categories, cycle 1 with an average of 58.11 has sufficient categories and cycle 2 with an average of 80.30 has a very good category. Experiencing an increase in learning activities in the pre cycle to cycle 1 of 13.65 and in cycle 1 to cycle 2 an increase of 22.19. The increase in learning activities has an effect on the learning outcomes proven from the acquisition of pre-cycle action results reached an average of 59.34 to 67.84 in cycle 1 and an increase in cycle 2 to 73.26 . There was an increase in learning outcomes in the pre-cycle to cycle 1 actions of $5.42 \%$, and increased in cycle 1 to cycle 2 by $8.50 \%$.
\end{abstract}

Keyword: Activities, Learning Outcomes, Role Playing, and Puppet Dolls.

Abstrak. Tujuan penelitian ini adalah untuk meningkatkan aktivitas dan hasil belajar peserta didik dalam mata pelajaran IPS dengan menggunakan model pembelajaran. Jenis penelitian ini adalah penelitian tindakan kelas yang telah dilaksanakan dalam dua siklus.Pada setiap siklus melalui 4 tahapan yaitu perencanaan, tindakan, observasi dan refleksi. Penelitian ini dilaksanakan di SD Negeri Patemon 01 dengan subjek penelitian peserta didik kelas IV SD Negeri Patemon 01 dengan jumlah 26 peserta didik. Alat pengumpulan data menggunakan adalah wawancara, observasi, dan tes. Hasil penelitian menunjukkan bahwa dengan penerapan model pembelajaran kooperatif tipe Role Playing berbantuan media boneka wayang dapat meningkatkan aktivitas dan hasil belajar IPS pada pembelajaran tematik peserta didik kelas IV SD Negeri Patemon 01. Hal tersebut dapat dibuktikan dari perolehan hasil aktivitas belajar dan hasil belajar IPS yaitu pada aktivitas tindakan pra siklus dengan rata-rata 44,46 memiliki kategori cukup, siklus 1 dengan rata-rata 58,11 memiliki kategori cukup dan siklus 2 dengan rata-rata 80,30 memiliki kategori sangat baik. Mengalami peningkatan aktivitas belajar pada pra siklus ke siklus 1 sebesar 13,65 dan pada siklus 1 ke siklus 2 mengalami peningkatan sebesar 22,19. Adanya peningkatan aktivitas belajar berpengaruh pada hasil belajar terbukti dari perolehan hasil tindakan pra siklus mencapai rata-rata 59,34 menjadi 67,84 pada siklus 1 dan peningkatan pada siklus 2 menjadi 73,26. Terjadi peningkatan hasil belajar pada tindakan pra siklus ke siklus 1 sebesar 5,42\%, dan mengalami peningkatan pada siklus 1 ke siklus 2 sebesar 8,50\%.

Kata Kunci: Aktivitas, Hasil belajar, Role Playing, dan Boneka Wayang. 


\section{Pendahuluan}

Pendidikan merupakan suatu pilar yang paling utama dalam pembentukan mental dan sikap dari diri seorang individu. Pendidikan bagi kehidupan individu merupakan hal yang sangatlah penting, karena dengan adanya pendidikan akan berpengaruh dalam perubahan hidup yang dapat dialami oleh setiap individu. Perubahan yang dapat dilihat dari individu setelah menerima pendidikan adalah terbentuknya pola pikir dan sikap serta perilaku individu menuju arah yang lebih baik. Pendidikan pada dasarnya dapat disebut juga dengan ilmu yang secara normatif yang artinya ilmu yang tidak hanya dapat menjelaskan pemahaman akan pendidikan, namun juga dapat memberitahukan bahwa pentingnya pencapaian hasil yang dapat dilihat dan diuji dari nilai hidup yang bertujuan menjadi lebih baik. Tercapainya tujuan tersebut dapat terwujud dengan adanya proses pembelajaran dari adanya proses interaksi yang terjadi antara pendidik dan peserta didik.

Permendikbud No. 65 tahun 2013 yang berisi tentang Standar $\frac{\text { Proses Pendidikan Dasar dan }}{{ }^{*} \text { surel korespondensi: } 292015068 @ \text { student.uksw.edu }}$
Menengah yang menyatakan bahwa proses pembelajaran pada satuan pendidikan yang akan dilaksanakan dalam proses pembelajaran didalamnya harus mencakup pembelajaran yang interaktif, inspiratif, menyenangkan, menantang, dan memotivasi setiap peserta didik untuk berpartisipasi dalam aktivitasaktivitas belajar dan memberikan kesempatan untuk mengembangkan kreatifitas dan kemandirian para peserta didiknya. Di dalam proses pembelajaran yang dilakukan antara guru dan peserta didik sebaiknya dapat dikemas menjadi suatu pembelajaran yang menyenangkan sehingga dapat menumbuhkan motivasi belajar peserta didik untuk melakukan aktivitas-aktivitas belajarnya selama proses belajar mengajar itu berlangsung.

Keberhasilan dalam proses pembelajaran yang dapat dipengaruhi adanya beberapa faktor yang berperan didalam semua proses kegiatan pembelajaran. Adapun faktor-faktor yang berperan adalah peserta didik, guru dan kesiapan dalam pembelajaran seperti metode, sarana, dan prasarana (media pembelajaran), model pembelajaran, 
dan pendekatan pembelajaran yang digunakan untuk mendukung keberhasilan dalam mencapai tujuan pembelajaran. Namun dalam pelaksanaan pembelajaran dengan kondisi nyatanya masih terdapat hambatan dalam proses pelaksanaan pembelajarannya seperti contohnya pelaksanaan pembelajaran tidak sepenuhnya dapat meningkatkan kemampuan belajar peserta didik dalam menerapkan konsep pembelajaran yang telah dipelajari sehingga berpengaruh pada rendahnya mutu pembelajaran. Rendahnya mutu pendidikan yang kemudian dapat diartikan bahwa masih kurangnya keefektifan proses pembelajaran yang dilakukan oleh peserta didik dan guru. Yang menjadi penyebabnya dapat berasal dari peserta didik, guru, sarana dan prasarana pembelajaran yang diterapkan, kurangnya minat dan aktivitas belajar peserta didik yang membuat pembelajaran tidak kondusif dan efektif.

Berdasarkan hasil wawancara dengan guru wali kelas IV yang telah dilakukan di SD Negeri Patemon 01 yang telah menunjukkan bahwa kurangnya aktivitas-aktivitas belajar yang diulakukan oleh peserta didik sehingga didalam proses pembelajaran peserta didik terlihat sangat pasif pada mata pelajaran IPS sehingga dapat berpengaruh pada hasil belajarnya pada mata pelajaran IPS. Yang mana pengertian dari Ilmu Pengetahuan Sosial adalah kombinasi mata pelajaran yang memuat berbagai cabang ilmu-ilmu sosial yang diantaranya ilmu sosiologi, sejarah, geografi, ekonomi, politik, hukum dan budaya (Trianto, 2010: 171). Dengan mata pelajaran yang mencakup banyaknya materi yang dihafal, peserta didik kelas IV ini cenderung kurang aktif dan kurang memperhatikan materi pelajaran IPS pada saat guru memberikan pelajaran bahkan peserta didik terlihat bosan dengan pembelajaran yang disampaikan oleh guru. Dapat disadari bahwa materi pelajaran IPS yang memuat banyak sekali materi pelajaran yang dihafalkan membuat peserta didik jenuh dan bosan dan guru juga masih cenderung menggunakan model dan metode pembelajaran yang belum mengaktifkan peserta didik. Menurut pendapat Kristin \& Rahayu (2016: 86) yang menyatakan bahwa "Apabila 
proses pembelajaran jika sebagian besar materi hanya disampaikan dengan menerapkan model pembelajaran ceramah dan tanya jawab akan membuat peserta didik kurang antusias dalam pembelajaran dan kurang dalam memahami materi yang dipelajari". Untuk mengatasi permasalahan tersebut guru sudah melakukan upaya metode pembelajaran dengan berdiskusi dengan kelompok namun upaya pembelajaran tersebut hanya dominan dilakukan oleh peserta didik yang aktif saja. Kurangnya aktivitas belajar peserta didik sangat berpengaruh pada hasil belajar peserta didik. Pada mata pelajaran Ilmu Pengetahuan Sosial (IPS) masih terdapat peserta didik yang belum memperoleh hasil yang maksimal dan kurang dari KKM yang telah ditentukan oleh pihak sekolah.Nilai Kriteria Ketuntasan Minimal (KKM) pada mata pelajaran IPS adalah 60.

Berdasarkan perolehan data pada pelaksanaan tindakan pra siklus dengan dilakukannya pemberian soal pretest dengan materi "Pemanfaatan Sumber Daya Alam" telah menunjukkan bahwa hasil belajar peserta didik pada mata pelajaran
Ilmu Pengetahuan Sosial (IPS) belum memenuhi Kriteria Ketuntasan Minimum (KKM) yang telah ditentukan pada indikator keberhasilan yaitu jika 80\% peserta didik mendapatkan nilæ60 untuk mata pelajaran IPS akan mengalami ketuntasan, namun pada perolehan hasil pretest terdapat 35\% dengan jumlah peserta didik 9 yang mengalami ketuntasan hasil belajar sedangkan 17 peserta didik dengan persentase $65 \%$ belum mendapatkan ketuntasan hasil belajar pada mata pelajaran IPS.

$$
\text { Selain melatarbelakangi }
$$

rendahnya aktivitas belajar dan hasil belajar IPS yang diperoleh peserta didik permasalahan yang dialami oleh guru adalah masih menerapkan metode pembelajaran ceramah untuk mengantarkan peserta didik memahami materi pelajaran yang disampaikan.Seperti yang telah disampaikan bahwa materi pelajaran IPS bersifat mata pelajaran yang menghafal dan membuat peserta didik cepat bosan serta kurang memperhatikan pembelajaran dalam mengikuti pelajaran IPS menjadi sulit bagi peserta didik untuk memahami materi tentang pemanfaatan sumber 
daya alam. Mata pelajaran IPS selain bersifat hafalan disamping itu juga sering dianggap kurang menarik jika disampaikan dengan metode ceramah yang dapat berpengaruh pada kurangnya aktivitas belajar peserta didik, sehingga permasalahan tersebut muncul dengan membuat peserta didik kurang berminat dalam mengikuti pelajaran IPS. Karena aktivitas belajar merupakan keseluruhan dari aktivitas-aktivitas peserta didik yang dilakukan selama proses belajar, yang dimulai dari kegiatan fisik sampai kegiatan psikis (Rahmadani \& Anugraheni, 2017: 242). Aktivitas belajar yang dilakukan oleh peserta didik itu sangatlah penting karena dapat mengubah tingkah lakunya didalam proses pembelajaran yang sedang berlangsung (Sadirman, 2011: 95). Perubahan tingkah laku yang dialami peserta didik juga dapat disebut dengan hasil belajar. Menurut pendapat Cintia, dkk (2018: 71) "Hasil belajar merupakan kemampuan baru yang dimiliki oleh peserta didik yang dapat diperoleh setelah melakukan proses belajar yang didalamnya mencakup aspek kognitif, afektif dan psikomotor".
Berdasarkan hasil observasi yang telah dilakukan di kelas IV SD Negeri Patemon 01, nampak bahwa guru sangat perlu memilih model pembelajaran yang tepat, kreatif serta inovatif dalam pelaksanaan proses pembelajaran yang nantinya dapat menumbuhkan rasa antusias dan menyenangkan, menumbuhkan aktivitas-aktivitas belajar peserta didik, menciptakan suasana pembelajaran yang kondusif dan efektif sehingga akan membantu peserta didik dalam memahami konsep materi pelajaran IPS yang dipelajari dapat diterima dengan baik dan peserta didik pun dapat mencapai hasil belajar yang maksimal sesuai dengan batas ketuntasan yang diterapkan oleh pihak sekolah.

Untuk mengatasi permasalahan tersebut maka dilakukannya upaya untuk menerapkan model pembelajaran kooperatif tipe Role Playing berbantuan media boneka wayang sebagai alternatif pembelajaran yang dapat menumbuhkan aktivitas belajar peserta didik dalam bermain peran. Model pembelajaran kooperatif mempunyai tujuan didalam proses pembelajaran untuk membuat peserta 
didik belajar didalam kelompok untuk bersama-sama belajar menyelesaikan tugas yang diberikan oleh guru untuk mencapai tujuan pembelajaran. Model pembelajaran kooperatif dapat bertujuan untuk mencapai hasil belajar yang berupa prestasi belajar secara akademik dan dapat menumbuhkan sikap toleransi serta pengembangan keterampilan sosial peserta didik (Suprijono, 2015: 80). Oleh peneliti model pembelajaran kooperatif dikombinasi dengan kegiatan bermain peran atau Role Playing dengan tujuan peserta didik tidak hanya menyelesaikan tugas dari guru dalam kegiatan berdiskusi namun dapat terlibat secara langsung dan mempraktikkan tugas yang diberikan oleh guru dengan kegiatan bermain peran.

Model pembelajaran kooperatif tipe Role Playing merupakan model pembelajaran dengan cara bermain peran yang dapat melibatkan interaksi antara dua peserta didik atau lebih yang memerankan suatu topik atau situasi tertentu (Yamin, 2011: 152). Role Playing juga merupakan suatu model pembelajaran yang dalam penguasaan bahan-bahan pelajarannya dapat dilakukan dengan melalui adanya pengembangan imajinasi dan penghayatan peran yang akan diperankan oleh peserta didik sesuai dengan tema dan tokoh yang akan diperankan (Komalasari, 2013: 80).

Kelebihan model pembelajaran kooperatif tipe Role Playing adalah dapat melibatkan peserta didik untuk berpartisipasi dan mempunyai kesempatan belajar dengan kemampuan bekerja sama dengan sesama anggota kelompok. Menurut Djamarah dan Aswan (2010: 67) yang menyatakan adanya kelebihan model ini yaitu sebagai berikut : peserta didik dilatih untuk memahami dan mengingat isi dari bahan yang akan diperankan, peserta didik akan lebih berinisiatif dan kreatif dalam bermain peran, peserta didik dapat memupuk bakat untuk bermain peran, peserta didik dapat menjalin kerjasama antar pemain bermain peran, peserta didil dapat membiasakan diri untuk menerima dan mengabdi tanggung jawab dengan sesamanya, kebiasaan peserta didik utnuk menggunakan bahasa lisan yang baik.

Pada dasarnya peserta didik yang masih sering bermain, penggunaan media sangatlah 
dibutuhkan untuk membantu peserta didik dalam proses pembelajaran yang berlangsung. Penggunaan media boneka dalam penelitian ini bertujuan sebagai "Media cerita yang memiliki banyak kelebihan salah satunya adalah dapat mengundang minat dan perhatian peserta didik dalam memerankan tokoh sesuai dengan yang diperankannya" (Ramadhan, 2017: 6-7). Penggunaan boneka wayang yang digunakan sebagai media, peserta didik dapat terlibat secara langsung dalam memainkan boneka wayang pada saat kegiatan bermain peran berlangsung. Dalam hal ini, penggunaan boneka wayang dapat mengalihkan setiap perhatian dan mengekspresikan serta menyatakan perasaan peserta didik dalam memainkan perannya dalam kegiatan bermain peran. Bahkan penggunaan media boneka wayang bisa mendorong tumbuhnya imajinasi para peserta didik yang terlibat secara langsung.

Berdasarkan latar belakang tersebut maka peneliti telah melakukan penelitian tindakan kelas dengan judul "Peningkatan Aktivitas dan Hasil Belajar IPS Kelas IV Melalui Penerapan Model Pembelajaran
Kooperatif Tipe Role Playing Berbantuan Boneka Wayang" pada peserta didik kelas IV SD Negeri Patemon 01.

\section{Metode}

Penelitian ini telah dilaksanakan dengan menggunakan jenis penelitian yaitu Penelitian Tindakan Kelas (Classroom Action Research). Permasalahan yang diangkat dalam penelitian tindakan kelas ini harus benar-benar merupakan permasalahan yang dialami oleh guru sebagai pendidik dalam praktik pembelajaran di kelas, bukan melainkan praktik yang disarankan yang dapat ditentukan oleh pihak luar termasuk oleh kepala sekolah sebagai mitra sekolah. Permasalahan yang dapat diangkat dalam penelitian tindakan kelas dapat bersumber pada peserta didik, guru, bahan ajar, sarana dan prasarana pembelajaran dan hasil belajar peserta didik (Slameto 2015: 48). Penelitian tindakan kelas ini dilaksanakan dalam dua siklus dengan setiap siklusnya meliputi tahap perencanaan, tindakan, observasi dan refleksi dengan menggunakan alur siklus penelitian tindakan kelas menurut Mulyasa (2012: 73) . Hasil 
dari refleksi akan menjadi bahan perbaikan pada perencanaan tindakan yang akan dilaksanakan di siklus kedua.

Penelitian ini menggunakan teknik pengumpulan data wawancara, observasi, dan tes.Kemudian data yang telah diperoleh dalam penelitian ini lalu di analisis hasilnya dengan menggunakan teknik deskripsi. Untuk menganalisis data variabel bebas dengan menggunakan teknik kualitatif dalam menganalisis data yang diperoleh dari hasil observasi tindakan guru terhadap penerapan model pembelajaran kooperatif tipe Role Playing berbantuan media wayang. Teknik analisis data menggunakan cara analisis kuantitatif pada perolehan data aktivitas belajar peserta didik. Sedangkan untuk menghitung perbandingan aktivitas dan hasil belajar IPS menggunakan teknik analisis komparatif pada siklus 1 dan siklus 2 .

Lokasi penelitian daalam penelitian ini adalah SD Negeri Patemon 01. Sebagai subjek dalam penelitian ini adalah peserta didik kelas IV SD Negeri Patemon 01, dengan jumlah peserta didik sebanyak 26 yang terdiri dari 15 peserta didik laki-laki dan 11 peserta didik perempuan.

\section{Hasil dan Pembahasan}

Proses penelitian yang telah dilaksanakan dalam 2 siklus yang masing-masing siklus terdiri dari 4 tahapan yang dilakukan, yaitu : tahap perencanaan, tahap pelaksanaan tindakan, tahap observasi dan tahap refleksi.

Sebelum dilakukannya penelitian tindakan kelas, peneliti terlebih dahulu melaksanakan wawancara dengan wali kelas IV seputar permasalahan yang dialami oleh guru sebagai pendidik pada saat melakukan proses pembelajaran pada mata pelajaran IPS, melakukan observasi mengamati pelaksanaan proses pembelajaran pada mata pelajaran IPS, melakukan observasi tentang aktivitas-aktivitas belajar peserta didik yang dapat mempengaruhi hasil belajarnya. Pada penelitian ini akan menunjukkan adanya peningkatan pada aktivitas belajar dan hasil belajar peserta didik pada mata pelajaran IPS. Kegiatan penelitian diawali dengan melakukan observasi aktivitas belajar peserta didik dan melakukan tindakan pra 
siklus dengan melakukan uji soal pretest untuk memperoleh hasil belajar pada mata pelajaran Ilmu Pengetahuan Sosial peserta didik kelas IV SD Negeri Patemon 01.

Setelah dilakukannya observasi aktivitas belajar peserta didik pada tindakan pra siklus, siklus 1 dan siklus 2 telah menunjukkan adanya hasil bahwa aktivitas belajar peserta didik mengalami peningkatan setelah dilakukannya tindakan penerapan model pembelajaran kooperatif tipe Role Playing berbantuan media boneka wayang. Berikut data perbandingan aktivitas belajar peserta didik pada tindakan pra siklus, siklus 1 dan siklus 2 seperti terlihat pada tabel 1.

Tabel 1 .Perbandingan Hasil Observasi Aktivitas Belajar Peserta Didik

\begin{tabular}{|c|c|c|c|c|c|c|c|}
\hline \multirow[t]{2}{*}{ Rentang } & \multirow[t]{2}{*}{ Kriteria } & \multicolumn{2}{|c|}{ Pra Siklus } & \multicolumn{2}{|c|}{ Siklus 1} & \multicolumn{2}{|c|}{ Siklus 2} \\
\hline & & $\begin{array}{l}\text { Jumlah } \\
\text { Siswa }\end{array}$ & $\%$ & $\begin{array}{l}\text { Jumlah } \\
\text { Siswa }\end{array}$ & $\%$ & $\begin{array}{l}\text { Jumlah } \\
\text { Siswa }\end{array}$ & $\%$ \\
\hline $24-39$ & Kurang & 10 & $39 \%$ & 1 & $4 \%$ & 0 & $0 \%$ \\
\hline $40-58$ & Cukup & 11 & $42 \%$ & 17 & $65 \%$ & 1 & $4 \%$ \\
\hline $59-77$ & Baik & 5 & $19 \%$ & 7 & $27 \%$ & 10 & $38 \%$ \\
\hline $78-96$ & $\begin{array}{l}\text { Sangat } \\
\text { Baik }\end{array}$ & 0 & 0 & 1 & $4 \%$ & 15 & $58 \%$ \\
\hline \multicolumn{2}{|c|}{ Jumlah } & 26 & $100 \%$ & 26 & $100 \%$ & 26 & $100 \%$ \\
\hline \multicolumn{2}{|c|}{ Rata-rata } & \multicolumn{2}{|c|}{44,46} & \multicolumn{2}{|c|}{58,11} & \multicolumn{2}{|c|}{80,30} \\
\hline \multicolumn{2}{|c|}{ Kriteria } & \multicolumn{2}{|c|}{ Cukup } & \multicolumn{2}{|c|}{ Cukup } & \multicolumn{2}{|c|}{ Sangat Baik } \\
\hline
\end{tabular}

Berdasarkan data yang telah diperoleh pada tabel 1, maka dapat dilihat pada tindakan pra siklus terdapat 10 peserta didik dengan persentase $39 \%$ memiliki kriteria kurang, sebanyak 11 peserta didik dengan persentase $42 \%$ memiliki kriteria cukup, sebanyak 5 peserta didik dengan persentase 19\% memiliki kriteria baik dan tidak ada peserta didik yang memiliki kriteria sangat baik pada hasil observasi aktivitas belajar peserta didik sebelum dilakukannya tindakan penerapan model pembelajaran kooperatif tipe Role Playing berbantuan media boneka wayang dengan perolehan hasil rata-rata 44,46 dengan kriteria cukup. Pada pembelajaran yang dilaksanakan pada siklus 1 telah diterapkan model pembelajaran kooperatif tipe Role Playing 
berbantuan media boneka wayang telah menunjukkan adanya peningkatan aktivitas belajar peserta didik yaitu terdapat 1 peserta didik dengan persentase $4 \%$ memiliki kriteria kurang, sebanyak 17 peserta didik dengan persentase 65\% memiliki kriteria cukup, sebanyak 7 peserta didik dengan persentase $27 \%$ memiliki kriteria baik dan 1 peserta didik dengan persentase $4 \%$ memiliki kriteria sangat baik pada observasi aktivitas peserta didik pada siklus 1 dengan perolehan hasil rata-rata 58,11 dengan kriteria cukup .

Pada pembelajaran siklus 2 dengan melakukan penerapan model pembelajaran kooperatif tipe Role Playing berbantuan media boneka wayang dengan adanya perbaikan dari hasil evaluasi pembelajaran siklus 1 , terjadi peningkatan aktivitas belajar peserta didik pada siklus 2 yaitu dengan hasil, tidak ada peserta didik yang berada pada kriteria kurang pada siklus 2, kemudian terdapat 1 peserta didik dengan persentase $4 \%$ memiliki kriteria cukup, sebanyak 10 peserta didik dengan persentase 58\% memiliki kriteria baik dan 15 peserta didik dengan persentase 58\% memiliki kriteria sangat baik pada hasil observasi aktivitas peserta didik pada siklus 2 dengan perolehan hasil rata-rata 80,30 dengan kriteria sangat baik.

Terjadi peningkatan aktivitas belajar peserta didik pada setiap siklusnya dengan penerapan model pembelajaran kooperatif tipe Role Playing berbantuan media boneka wayang.Berdasarkan hasil penelitian peningkatan aktivitas belajar peserta didik ini sangat berpengaruh pada hasil belajar kelas IV SD Negeri Patemon 01 pada mata pelajaran Ilmu Pengetahuan Sosial (IPS). Hasil belajar peserta didik dalam mata pelajaran IPS mengalami peningkatan pada tindakan pra siklus, siklus 1 hingga siklus 2. Berikut data perbandingan adanya peningkatan hasil belajar peserta didik dalam mata pelajaran IPS yang dapat dilihat pada tabel 2 . 
Tabel 2. Perbandingan Hasil Belajar IPS pada tindakan Pra siklus, Siklus 1 dan Siklus 2

\begin{tabular}{|c|c|c|c|c|c|c|c|}
\hline \multirow[t]{2}{*}{ Kategori } & \multirow[t]{2}{*}{ Nilai } & \multicolumn{2}{|c|}{ Pra Siklus } & \multicolumn{2}{|c|}{ Siklus 1} & \multicolumn{2}{|c|}{ Siklus 2} \\
\hline & & $\begin{array}{c}\text { Jumlah } \\
\text { siswa }\end{array}$ & $\%$ & $\begin{array}{c}\text { Jumlah } \\
\text { Siswa }\end{array}$ & $\%$ & $\begin{array}{c}\text { Jumlah } \\
\text { Siswa }\end{array}$ & $\%$ \\
\hline Tuntas & $\geq 60$ & 9 & $35 \%$ & 18 & $69 \%$ & 23 & $88 \%$ \\
\hline $\begin{array}{l}\text { Tidak } \\
\text { Tuntas }\end{array}$ & $\leq 60$ & 17 & $65 \%$ & 8 & $31 \%$ & 3 & $12 \%$ \\
\hline \multicolumn{2}{|c|}{ Jumlah } & 26 & $100 \%$ & 26 & $100 \%$ & 26 & $100 \%$ \\
\hline \multicolumn{2}{|c|}{ Rata-rata } & \multicolumn{2}{|c|}{59,34} & \multicolumn{2}{|c|}{67,84} & \multicolumn{2}{|c|}{73,26} \\
\hline
\end{tabular}

Berdasarkan data yang telah diperoleh hasil belajar peserta didik pada tabel 2, maka dapat dilihat dari tindakan pra siklus telah menunjukkan hasil terdapat peserta didik dengan kategori tuntas sebanyak 9 peserta didik dengan persentase $35 \%$ dan peserta didik dengan kategori tidak tuntas sebanyak 17 peserta didik dengan persentase 65\%. Nilai rata-rata yang diperoleh pada tindakan pra siklus adalah 59,34.

Selanjutnya pada pembelajaran siklus 1 telah menerapkan model pembelajaran kooperatif tipe Role Playing berbantuan media boneka wayang, telah menunjukkan adanya peningkatan hasil belajar mata pelajaran IPS yaitu dengan perolehan hasil, terdapat peserta didik dengan kategori tuntas sebanyak 18 peserta didik dengan persentase 69\% dan peserta didik dengan kategori tidak tuntas sebanyak 8 peserta didik dengan persentase 31\%. Terjadi peningkatan pada nilai rata-rata setelah dilakukannya penelitian yaitu sebesar 67,84 pada siklus 1 .

Berdasarkan hasil yang diperoleh pada siklus 1 maka perlu dilakukannya perbaikan pembelajaran pada siklus 2 dengan menerapkan model pembelajaran kooperatif tipe Role Playing berbantuan media boneka wayang sesuai dengan hasil refleksi siklus 1. Pada pembelajaran siklus 2 telah menunjukkan adanya peningkatan kembali pada hasil belajar peserta didik yaitu sebanyak 23 peserta didik dengan persentase 88\% yang memiliki kategori tuntas dan peserta didik dengan kategori tidak tuntas terdapat 3 peserta didik dengan persentase $12 \%$. Pembelajaran pada siklus 2 telah mengalami peningkatan nilai rata-rata menjadi 73,26. 
Sebagai pembahasan dari hasil penelitian yang dilakukan di SD Negeri Patemon 01 bahwa terdapat kendalakendala yang dialami pada pelaksanaan penerapan penelitian siklus 1 pada aktivitas peserta didik yaitu peserta didik belum terbiasa melakukan aktivitas belajar dengan melaksanakan proses pembelajaran dengan model pembelajaran Role Playing ini, peserta didik belum sepenuhnya antusias dalam melakukan aktivitas dalam kegiatan bermain peran, aktivitas belajar peserta didik masih di dominasi oleh peserta didik yang lebih aktif. Berdasarkan kendala-kendala yang dialami pada siklus 1 tentang aktivitas belajar peserta didik, maka pada siklus 2 dilakukannya perbaikan yaitu dengan menuntun peserta didik untuk memahami aktivitas-aktivitas yang dilakukan pada penerapan model pembelajaran Role Playing, peserta didik diberikan pengarahan dalam melakukan aktivitas belajar dengan kegiatan bermain peran dan memotivasi semua peserta didik supaya berkeinginan untuk terlibat secara aktif akan aktivitas-aktivitas belajar yang telah dipersiapkan guru. Setelah dilakukan perbaikan proses pembelajaran di setiap siklusnya telah menunjukkan adanya peningkatan aktivitas belajar peserta didik dari tindakan pra siklus hingga siklus 2, yaitu terjadi peningkatan nilairatarata dari tindakan pra siklus 44,46 dengan kategori cukup, kemudian mengalami peningkatan setelah dilakukan tindakan pada siklus 1 dan siklus 2 dengan nilai rata-rata 58,11 dengan kriteria cukup kemudian meningkat menjadi 80,30 dengan kriteria sangat baik. Terjadi peningkatan hasil pada aktivitas belajar peserta didik yang telah dilakukan dalam menyelesaikan soal yang dibandingkan dengan penelitian sebelumnya. Penelitian ini diperkuat dengan oleh pendapat Roetiyah (2012: 93) dengan pendapatnya bahwa penerapan model pembelajaran Role Playingakan dapat lebih menarik perhatian peserta didik dalam melakukan proses pembelajaran dan membuat peserta didik lebih aktif dalam melakukan aktivitas-aktivitas belajar dengan kegiatan bermain peran atau menyaksikan kegiatan bermain peran.

Upaya untuk mengatasi kendalakendala yang dialami pada aktivitas belajar peserta didik telah 
berpengaruh pada hasil belajar peserta didik kelas IV SD Negeri Patemon 01 pada mata pelajaran IPS setelah dilakukan tindakan dengan menerapkan model pembelajaran kooperatif tipe Role Playing berbantuan media boneka wayang. Peningkatan dari nilai ketuntasan peserta didik pada tindakan pra siklus dengan persentase $35 \%$ kemudian mengalami peningkatan pada siklus 1 dengan persentase $69 \%$, karena pada siklus 1 ketuntasan hasil belajar belum mencukupi persentase ketuntasan sesuai dengan indikator keberhasilan maka dilakukannya perbaikan proses pembelajaran pada siklus 2 sehingga mengalami peningkatan sebesar 88\%. Dengan telah melampaui indikator keberhasilan yang telah ditentukan yaitu $80 \%$. Peningkatan hasil belajar juga dapat dilihat dari peningkatan nilai rata-rata, pada tindakan pra siklus menunjukkan hasil rata-rata 59,34 kemudian mengalami peningkatan pada siklus 1 dan siklus 2 yaitu 67,84 menjadi 73,26.

Sejalan dengan penelitian yang dilakukan oleh Kurniasih (2015: 2) menunjukkan adanya perolehan hasil pada mata pelajaran IPS dengan menggunakan model pembelajaran kooperatif tipe Role Playingsehingga dapat meningkatkan hasil belajar peserta didik kelas VA SD Negeri 2 Klaten dengan menunjukkan hasil rata-rata nilai tes peserta didik sebelum tindakan 63,04 dengan persentase $47,83 \%$, pada siklus 1 69,57 dengan persentase 69,57 dan siklus 2 78,26 dengan persentase 82,61\%. Sedangkan menurut pendapat Wardani (2016: 8-10) dengan judul "Pengaruh Metode Role Playing Terhadap Hasil Belajar IPS Peserta Didik Kelas V SDN Pontianak Kota" yang dapat dibuktikan dengan hasil analisis data posttest diperoleh $t_{\text {hitung }}>t_{\text {tabel }}$ yaitu 2,0734 $>2,0465$ dan Djaila dkk (2017: 13-15) mengemukakan pendapatnya tentang penerapan metode Role Playing telah dapat meningkatkan aktivitas belajar baik guru maupun peserta didik dibuktikan dengan perolehan hasil analisis tes akhir pada penelitian tindakan kelas yang sudah dilaksanakan, yang terjadi dalam siklus I dan siklus II peserta didik telah mengalami peningkatan hasil belajar secara klasikal yaitu sebesar $38 \%$ yaitu dari persentase 54\% pada tes akhir tindakan siklus I menjadi 
92\% pada siklus II.. Berdasarkan ketuntasan hasil belajar peserta didik pada penelitian yang telah dilakukan sebelumnya, sama-sama menunjukkan hasil peningkatan pada rata-rata hasil belajar di setiap siklus pembelajaran yang telah dilakukan. Peningkatan hasil belajar dapat terjadi karena hasil belajar adalah kemampuankemampuan yang dimiliki oleh setiap peserta didik setelah menerima pengalaman belajarnya sehingga menghasilkan peningkatan pada hasil belajarnya (Sukoco \& Mediatati, 2015).

Pembedaan lain dalam penelitian ini dengan penelitian yang sebelumnya, penelitian yang dilakukan oleh Kurniasih (2015: 2) hanya menggunakan langkah-langkah model pembelajaran kooperatof tipe Role Playing tanpa menggunakan bantuan media pembelajaran, namun pada penelitian ini menerapkan model pembelajaran kooperatif tipe Role Playing dengan berbantuan media boneka wayang. Menurut Ramadhan (2017: 10-11) "Model pembelajaran yang dikombinasi dengan penggunaan boneka memiliki beberapa tujuan yaitu dapat membangkitkan kecerdasaan peserta didik secara penuh melalui penggabungan gerak fisik dengan aktivitas intelektual, membantu peserta didik tidak mudah lupa tentang materi pelajaran, membantu peserta didik untuk lebih termotivasi untuk belajar lebih baik lagi, dan mampu membangkitkan kreativitas serta meningkatkan kemampuan psikomotor peserta didik".

\section{Simpulan}

Berdasarkan hasil penelitian dan analisis data, dapat ditarik kesimpulan bahwa melalui penerapan langkahlangkah model pembelajaran kooperatif tipe Role Playing berbantuan media boneka wayang dapat meningkatkan aktivitas dan hasil belajar peserta didik kelas IV SD Negeri Patemon 01, hasil yang dapat dibuktikan dengan meningkatnya hasil rata-rata aktivitas belajar peserta didik dan persentase ketuntasan hasil belajar peserta didik dalam mata pelajaran IPS dari kondisi pra siklus, siklus 1 dan siklus 2 .

Hasil observasi yang telah dilakukan pada pelaksanaan pembelajaran telah menunjukkan bahwa peserta didik telah mengalami peningkatan yang dapat dilihat dari 
perubahan aktivitas belajar yang dilakukan oleh peserta didik di setiap siklusnya.Pada setiap siklusnya peserta didik mulai mengalami peningkatan yang tercermin pada antuasias dan keaktifan peserta didik dalam kegiatan bermain peran.Dengan kegiatan bermain peran peserta didik lebih aktif, komunikatif dan pembelajaran lebih menjadi menyenangkan dan efektif dibanding sebelumnya. Peningkatan hasil ratarata aktivitas belajar peserta didik pada pra siklus 44,46 menjadi meningkat pada siklus 1 yaitu 58.11 dan siklus 2 mengalami peningkatan menajdi 80,30.

Hasil perolehan hasil belajar IPS ditunjukkan pada nilai rata-rata peserta didik pada kondisi pra siklus 59,34 dan siklus 1 menjadi 67,84 serta mengalami peningkatan pada siklus 2 yaitu 73,26. Persentase peserta didik yang mencapai KKM pada tindakan pra siklus 35\% kemudian pada siklus 1 mengalami peningkatan 69\% dan pada siklus 2 mencapai 88\% jadi peningkatan hasil belajar IPS telah mencapai indikator keberhasilan 80\% seperti yang telah ditetapkan.

Berdasarkan analisis dari hasil penelitian tindakan kelas yang telah dilakukan selama dua siklus dapat disimpulkan bahwa penerapan model pembelajaran kooperatif tipe Role Playing berbantuan media boneka wayang dapat meningkatkan aktivitas dan hasil belajar IPS peserta didik pada kelas IV SD Negeri Patemon 01 pada Tahun Ajaran 2018/2019.

\section{Daftar Pustaka}

Cintia, N. I., Kristin, F., \& Anugraheni, I. (2018). Penerapan Model Pembelajaran Discovery Learning Untuk Meningkatkan Kemampuan Berpikir Kreatif dan Hasil Belajar Siswa. PERSPEKTIF Ilmu Pendidikan, 32(1) 69-77.

Djaila, M., Jamaludin , \& Hanis, H. (2014). Penerapan Metode Bermain Peran untuk Meningkatkan Hasil Belajar IPS pada Pokok Bahasan Kegiatan Jual Beli di Kelas III SDN Simdo. Jurnal Kreatif Tadulako Online ,5 (1), 101-116.

Djamarah, S. B \& Aswan, Z. (2010). Strategi Belajar Mengajar. Jakarta: Rineka Cipta.

Komalasari, K. (2013). Pembelajaran Kontekstual Konsep dan Aplikasi. Bandung: Refika Aditama. 
Kristin, F., \& Rahayu, D. (2016). Pengaruh Penerapan Model Discovery Learning Terhadap Hasil Belajar IPS Pada Siswa Kelas 4 SD . Scholaria, 6(1), 8492.

Kurniasih, S. (2015). Upaya Meningkatkan Prestasi Belajar IPS Dengan Model Pembelajaran Kooperatif Tipe Role Playing Pada Sisiwa Kelas VA SD Negeri 2 Klaten. Jurnal of Elementary Education, 1-3.

Yamin ,M. (2011). Paradigma Baru Pembelajaran . Jakarta: Gaung Persada.

Mulyasa , H. (2012). Penelitian

Tindakan Kelas . Bandung: Remaja Rosdakarya.

Rahmadani N, N., \& Anugraheni, I. (2017). Peningkatan Aktivitas Belajar Matematika Melalui Pendekatan Problem Based Learning Bagi Siswa Kelas 4 SD. Scholaria, 7(3) , 241-250.

Ramadhan, K. (2017). Peningkatan Keterampilan Berbicara Pada Mata Pelajaran Bahasa Indonesia Melalui Pendekatan Somantic Auditory Visualization Intellectually (SAVI) Berbantuan Boneka Tangan Pada Siswa Kelas
III A SDN Timuran Yogyakrta . 67.

Roestiyah. (2012). Strategi Belajar Mengajar. Jakarta: Rineka Cipta. Slameto. (2015). Implementasi Penelitian Tindakan Kelas, Scholaria, 5 (3). 47-58.

Sukoco, A., \& Mediatati, N. (2015). Meningkatkan Hasil Belajar Siswa Melalui Penerapan Model Pembelajaran problem Based Learning pada Pembelajaran PKn di Kelas VII SMP Stella Matutina Salatiga. Satya Widya, 31(2), 120-128.

Suprijono, A. (2015). Cooperative Learning Teori dan Aplikasi PAIKEM (Edisi Revisi). Yogyakarta: Pustaka Pelajar.

Trianto. (2010). Model Pembelajaran Terpadu. Surabaya: Bumi Aksara. Wardani, N. A. (2016). Pengaruh Metode Role Playing Terhadap Hasil Belajar IPS Peserta Didik Kelas V SD . Jurnal Pendidikan dan Pembelajaran, 8-10. 